\title{
Histone deacetylase inhibitor, trichostatin $A$, increases the chemosensitivity of anticancer drugs in gastric cancer cell lines
}

\author{
XIAOTIAN ZHANG ${ }^{1,2}$, MASAKAZU YASHIRO ${ }^{1}$, JUN REN $^{2}$ and KOSEI HIRAKAWA ${ }^{1}$ \\ ${ }^{1}$ Department of Surgical Oncology, Osaka City University Graduate School of Medicine, Osaka, Japan; \\ ${ }^{2}$ Department of Medical Oncology, Beijing Cancer Hospital, School of Oncology, \\ Peking University, 52 Fu Cheng Road, Beijing 100036, P.R. China
}

Received April 19, 2006; Accepted May 29, 2006

\begin{abstract}
Epigenetic alterations of the histone acetylation play an important role in the regulation of gene expression associated with cell cycles and apoptosis that may affect the chemosensitivity of gastric carcinomas. Recently, a histone deacetylase inhibitor, trichostatin A (TSA), was proven to be a chemo-sensitizer on human erythroleukemia cells. With the aim of improving the chemotherapeutic efficacy of gastric carcinoma, the effect of TSA on the chemosensitivity of several anticancer drugs in gastric carcinoma cells was investigated. Human gastric cancer cell lines, OCUM-8 and MKN-74, and 5 anticancer drugs, 5-fluorouracil (5-FU), paclitaxel (PTX), oxaliplatin (OXA), irinotecan (SN38) and gemcitabine (GEM) were used. In both gastric cancer cell lines, a synergistic anti-proliferative effect by the combination of TSA (30 ng/ml) with 5-FU, PTX or SN38 showed a synergistic anti-proliferative effect in OCUM-8 and MKN-74 cells. TSA increases the expression of $p 21, p 53, D A P K-1$ and the $D A P K-2$ gene in both OCUM-8 and MKN-74 cells. In conclusion, TSA is a promising chemotherapeutical agent in combination with anticancer drugs of 5-FU, PTX and SN38 in gastric cancer cell lines. The up-regulation of $p 53, p 21$, $D A P K-1$ and $D A P K-2$ might be associated with the synergistic effect of TSA.
\end{abstract}

\section{Introduction}

Gastric carcinoma remains one of the major causes of cancer deaths around the world $(1,2)$. Most patients with advanced gastric cancer need chemotherapy. Among the chemotherapeutical agents for gastric cancer, 5-fluorouracil (5-FU) remains the primary agent used, while recently several new drugs, including the taxanes such as paclitaxel (PTX), the third-

Correspondence to: Dr Masakazu Yashiro, Department of Surgical Oncology, Osaka City University Graduate School of Medicine, 1-2-3 Asahi-machi, Abeno-ku, Osaka 545-8585, Japan

E-mail: m9312510@med.osaka-cu.ac.jp

Key words: histone deacetylase inhibitor, gastric cancer, anticancer drugs, chemosensitivity, apoptosis, cell cycle, genes generation platinum derivative oxaliplatin (OXA), the topoisomerase-I inhibitor irinotecan (SN38), and the pyrimidine analog gemcitabine (GEM) have emerged. These agents provide a better prognosis for patients with advanced gastric cancer (3-6). Even so, the response rate is low (20-40\%). Combination chemotherapy using anticancer drugs achieves a better response rate, exceeding the efficacy of single treatment, but carries a high-risk of side effects. With the aim of improving the chemotherapeutic efficacy of gastric carcinoma, a novel combination regimen of anticancer drugs with a synergistic effect was investigated in this study.

The chemosensitivity of gastric carcinomas is influenced by changes in genes, including those known to be associated with cell cycles and apoptosis (7). There is increasing evidence that epigenetic alterations, such as the histone acetylation and the promoter methylation, play an important role in the regulation of gene expression associated with cell cycles and apoptosis (8). Histone acetylation relaxes the normally tight supercoiling of chromatin, enhancing the accessibility of DNA-binding transcriptional regulatory proteins to promoter regions, which is often associated with transcriptional activation of genes that regulate cell cycle progression, DNA replication and the apoptotic response to DNA damage. In contrast, histone deacetylation, catalyzed by histone deacetylase (HDAC), is often associated with transcriptional silencing through chromatin condensation. Aberrant levels of HDAC activity have been found in a variety of human malignancies and result in the repression of tumor-suppressor genes and the promotion of tumorigenesis (9). HDAC inhibitors represent a structurally diverse group of compounds that inhibit the deacetylation of histones, permitting the chromatin scaffolding to assume a more relaxed, open conformation, which generally promotes gene transcription. Because HDAC inhibitors induce apoptosis in neoplastic cells through multiple mechanisms, HDAC inhibitors are emerging as a promising new therapeutic tool for treatment of a variety of human tumors (10). HDAC inhibitors represent different mechanisms from conventional anticancer drugs. Inappropriate transcriptional repression mediated by HDACs is an important reason for the loss or down expression of tumor suppressor genes $(11,12)$. HDAC inhibitors induce differentiation (13), inhibit tumor growth (14), trigger apoptosis $(15,16)$, and regulate the cell cycle (17). HDAC inhibitors have recently been applied to some clinical trials such as a phase I study of suberoylanilide hydroxamic 
Table I. Primer sequences.

\begin{tabular}{|c|c|c|c|}
\hline Gene & & Sequence & Size of PCR products (bp) \\
\hline \multirow[t]{2}{*}{ Caspase-3 } & Sense & GGCATTGAGACAGACAGTGGTG & 152 \\
\hline & Antisense & GCACAAAGCGACTGGATGAACC & \\
\hline \multirow[t]{2}{*}{$p 21$} & Sense & GTACCCTTGTGCCTCGCTCA & 119 \\
\hline & Antisense & CCGGCGTTTGGAGTGGTAGA & \\
\hline \multirow[t]{2}{*}{ p53 } & Sense & AGCGATGGTCTGGCCCCTCCT & 120 \\
\hline & Antisense & CTCAGGCGGCTCATAGGGCAC & \\
\hline \multirow[t]{2}{*}{$D A P K 1$} & Sense & TCTACCAGCCACGGGACTTC & 134 \\
\hline & Antisense & GCTGGCCTGTGAGTAGACGT & \\
\hline \multirow[t]{2}{*}{$D A P K 2$} & Sense & GCATCGTGTCCCTGTGCAAC & 121 \\
\hline & Antisense & GCTTTCCTCCTGGCGATGTC & \\
\hline \multirow[t]{2}{*}{$D A P K 3$} & Sense & CCCAACCCACGAATCAAGCTC & 236 \\
\hline & Antisense & GCTGAGATGTTGGTGAGCGTC & \\
\hline \multirow[t]{2}{*}{ Bcl-2 } & Sense & GAGTACCTGAACCGGCACCT & 162 \\
\hline & Antisense & CAGGGTGATGCAAGCTCCCA & \\
\hline \multirow[t]{2}{*}{$R b$} & Sense & GGACCGAGAAGGACCAACTGA & 183 \\
\hline & Antisense & GTCTGGAAGGCTGAGGTTGCT & \\
\hline \multirow[t]{2}{*}{$G A P D H$} & Sense & ACCTGACCTGCCGTCTAGAA & 247 \\
\hline & Antisense & TCCACCACCCTGTTGCTGTA & \\
\hline
\end{tabular}

acids in patients with advanced solid tumors or hematological malignancies (18), and a phase II study of FR901228 in patients with cutaneous T-cell lymphoma or relapsed peripheral T-cell lymphoma (19).

The HDAC inhibitor trichostatinA (TSA) is one of the histone deacetylases that regulates gene expression epigenetically $(9,20)$. Since the inhibition of the cell growth by TSA at low nM concentrations has not been reported in nonneoplastic cells, TSA may be a prospective candidate chemotherapeutic agent to use in combination with other agents to form more effective regimens (20). TSA has been proven to be a radio- or chemo-sensitizer on human erythroleukemia cells (21). However, no studies have been conducted to elucidate the effect of TSA on the chemosensitivity of several anticancer drugs in gastric carcinoma cells. Here, we report that the HDAC inhibitor interacts with anticancer drugs in a highly synergistic manner in gastric cancer cell lines to induce the activation of apoptosis.

\section{Materials and methods}

Chemicals and anticancer drugs. A stock solution of TSA (Wako, Osaka, Japan) at $10 \mathrm{mg} / \mathrm{ml}$ was prepared in dimethyl sulfoxide (DMSO; Wako). Five anticancer drugs, 5-FU (Kyowa Hakko, Tokyo, Japan), PTX (Bristol-Myers, Wallingford, CT), Oxaliplatin (OXA; Yakult, Tokyo, Japan), irinotecan active metabolite SN38 (Yakult, Tokyo, Japan) and gemcitabine (GEM, Eli Lilly, Kobe, Japan), were used in this study. All reagents were formulated as recommended by their suppliers.
Cell culture and cell lines. The human gastric cancer cell lines OCUM-8 (22) and MKN-74 (23) were used in this study. OCUM-8 was cultured in Dulbecco's modified Eagle's medium (DMEM; Nikken Biomedical Laboratory, Kyoto, Japan), while MKN-74 was cultured in RPMI-1640 medium (Sigma, Tokyo, Japan). Both media were supplemented with $10 \%$ fetal bovine serum, $100 \mathrm{IU} / \mathrm{ml}$ penicillin (ICN Biomedical, Costa Mesa, CA), $100 \mu \mathrm{g} / \mathrm{ml}$ streptomycin (ICN Biomedical), and $0.5 \mathrm{mM}$ sodium pyruvate (Cambrex, Walkersville, MD). The cells were cultured at $37^{\circ} \mathrm{C}$ in a humidified atmosphere of $5 \%$ $\mathrm{CO}_{2}$ in air.

Cell growth assays. Cancer cells $\left(5 \times 10^{4}\right)$ were placed in each well of a 96-well plate. With or without the addition of TSA (30 ng/ml), and with or without anticancer drugs at the $\mathrm{IC}_{50}$, the plates were incubated for $72 \mathrm{~h}$ at $37^{\circ} \mathrm{C}$. The suppression of cell proliferation was examined by a 3-(4,5-dimethylthiazol-2-yl)-2,5-diphenyltetrazolium bromide (MTT; Sigma, St. Louis, MO) colorimetric assay in which the formazan product of MTT was measured as absorbance at $550 \mathrm{~nm}$ using a microtiter plate reader (Model 550; Bio-Rad Laboratories, Tokyo, Japan). The percentage of cell viability was determined as the ratio absorbance of the sample versus the control. The $\mathrm{IC}_{50}$ of each drug was determined as a drug concentration showing $50 \%$ cell growth inhibition as compared with the control cell growth. Six replicate wells were used for each drug concentration, and the testing was carried out independently for 3 times. The potential synergy between the drugs and TSA was evaluated as follows, using Drewinko's fraction method (24). The synergistic, semi-additive and antagonistic 

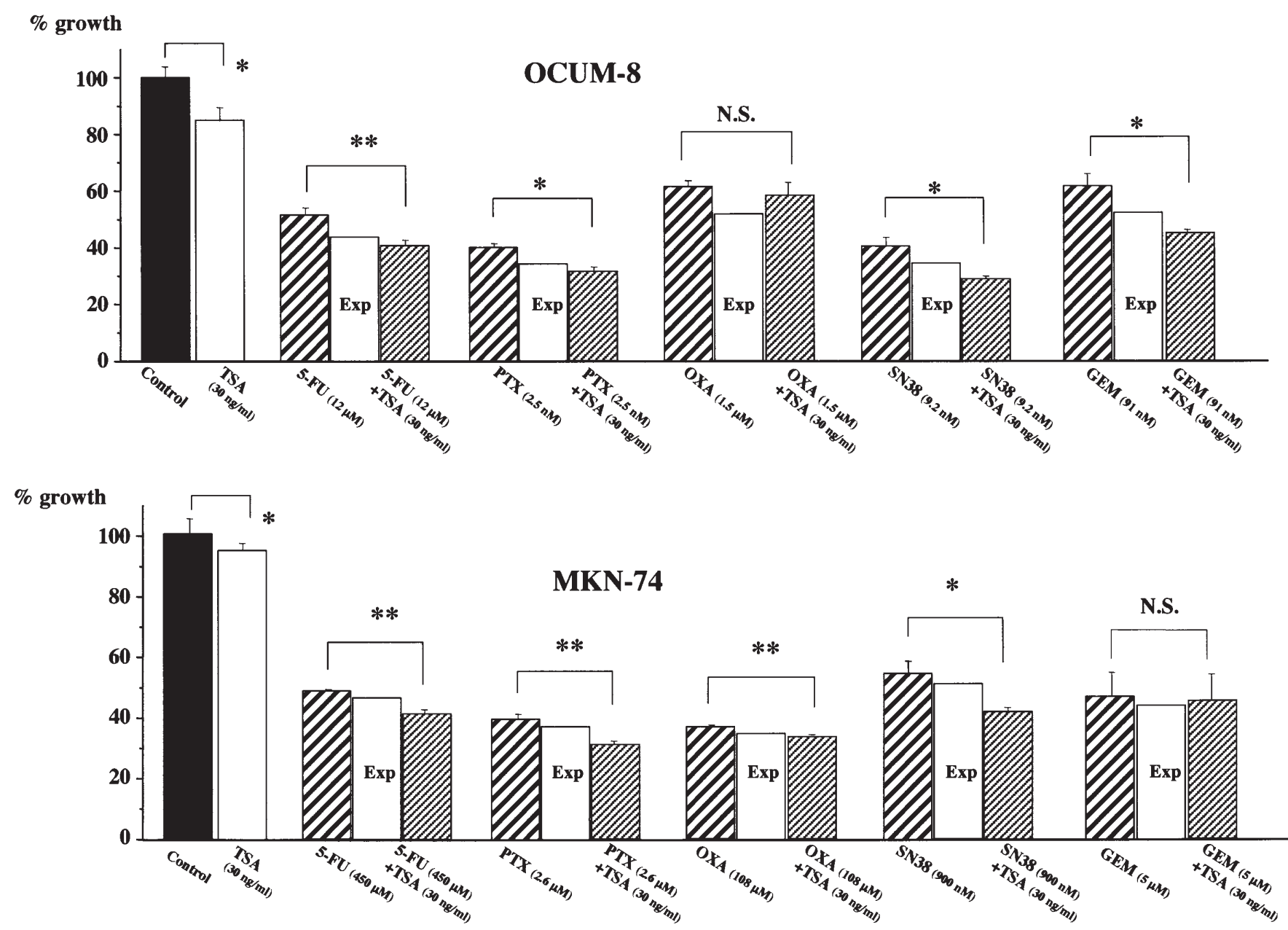

Figure 1. Synergistic or semi-additive effects of TSA with anticancer drugs on gastric cell lines. In both OCUM-8 and MKN-74 cells, a synergistic antiproliferative effect by the combination of TSA were observed in 5-FU, PTX or SN38. The combination of TSA with GEM showed a synergistic antiproliferative effect in OCUM- 8 cells. The combination of TSA with OXA showed a synergistic anti-proliferative effect in MKN-74 cells. No significant effect was observed with the combination of TSA with OXA in OCUM-8, with GEM in MKN-74. The synergistic, semi-additive and antagonistic interactions were determined when the value was less than the expected value, more than the expected value but less than the drugs' value, and more than the drugs' value, respectively. The expected value of the combined effects $(\%)=$ effects of anticancer drug/control x effects of TSA/ control x 100 was calculated. The results are presented as the mean of three independent experiences, and the bars indicate the SD. " $\mathrm{p}<0.05$; ** $\mathrm{p}<0.01$; compared with each anticancer drug alone. Exp, an expected additive value; NS, not significant.

interactions were determined when the value was less than the expected value, more than the expected value but less than the drugs' value, and more than the drugs' value, respectively. The expected value of the combined effects $(\%)=$ the effects of the anticancer drug/control $x$ the effects of the TSA/control x 100 was calculated.

Reverse transcription PCR. We examined the expression at the mRNA level of genes, including apoptosis related genes, caspase-3, bcl-2 and death associated protein kinase family members 1,2, and 3 (DAPK-1,DAPK-2 and DAPK-3), tumor suppressor gene $p 53$ and $R b$, and cell cycle regular $p 21^{\text {WAFI/Cipl }}$. The cells were seeded in a $100-\mathrm{mm}$ dish with the final concentration of $2.5 \times 10^{4}$ cells $/ \mathrm{ml}$, with or without TSA at $30 \mathrm{ng} / \mathrm{ml}$. After incubation of $48 \mathrm{~h}$, total cellular RNA was extracted from OCUM-8 and MKN-74 using Trizol reagent (Invitrogen, Carlsbad, CA) according to the manufacturer's protocol. After the genomic DNA was removed by DNAse, cDNA was prepared from $1 \mu \mathrm{g}$ of RNA with Maloney mouse leukemia virus reverse transcriptase (Invitrogen, Carlsbad, CA) using random primers (Invitrogen). The relevant cDNA were amplified by PCR using the primer pairs (Table I) with TaqDNA polymerase (Invitrogen) in a thermal cycler. The PCR conditions were as follows: predenaturation at $94^{\circ} \mathrm{C}$ for $3 \mathrm{~min}$, denaturation at $94^{\circ} \mathrm{C}$ for $30 \mathrm{sec}$, annealing at $59^{\circ} \mathrm{C}$ for $30 \mathrm{sec}$, extension at $72^{\circ} \mathrm{C}$ for $1 \mathrm{~min}$ with 35 cycles of the three repeated steps, and final incubation at $72^{\circ} \mathrm{C}$ for $10 \mathrm{~min}$. The PCR products were applied to $2 \%$ agarose gel and electrophoresed. The mRNA level of the each gene was normalized by the internal control glyceraldehyde-3-phosphate dehydrogenase $(G A P D H)$.

Statistical methods. The quantitative ratios of different groups were compared using the Student's t-test. Probability values of $\mathrm{P}<0.05$ were regarded as statistically significant. All statistical tests were two-sided.

\section{Results}

HDAC inhibitor increased the efficiency of anticancer drugs. Fig. 1 shows the effect of TSA and/or anticancer drugs on the proliferation of gastric cancer cells. TSA at $30 \mathrm{ng} / \mathrm{ml}$ suppressed 
Table II. $\mathrm{IC}_{50}$ of OCUM-8 and MKN-74 cells to anticancer drugs.

\begin{tabular}{lcc}
\hline & \multicolumn{2}{c}{$\mathrm{IC}_{50}$} \\
\cline { 2 - 3 } & OCUM-8 & MKN-74 \\
\hline 5-FU & $12.2 \pm 3.0 \mu \mathrm{M}$ & $0.6 \pm 0.1 \mathrm{mM}$ \\
PTX & $2.5 \pm 0.5 \mathrm{nM}$ & $2.6 \pm 0.1 \mu \mathrm{M}$ \\
OXA & $1.5 \pm 0.8 \mu \mathrm{M}$ & $108.3 \pm 10.5 \mu \mathrm{M}$ \\
SN38 & $9.2 \pm 1.8 \mathrm{nM}$ & $0.9 \pm 0.1 \mu \mathrm{M}$ \\
GEM & $90.8 \pm 9.2 \mathrm{nM}$ & $5.0 \pm 1.6 \mu \mathrm{M}$ \\
\hline
\end{tabular}

$\mathrm{IC}_{50}$ was determined as a concentration causing $50 \%$ growth inhibition for each cell line. The values indicated correspond to the result of three independent studies expressing in mean \pm SD.

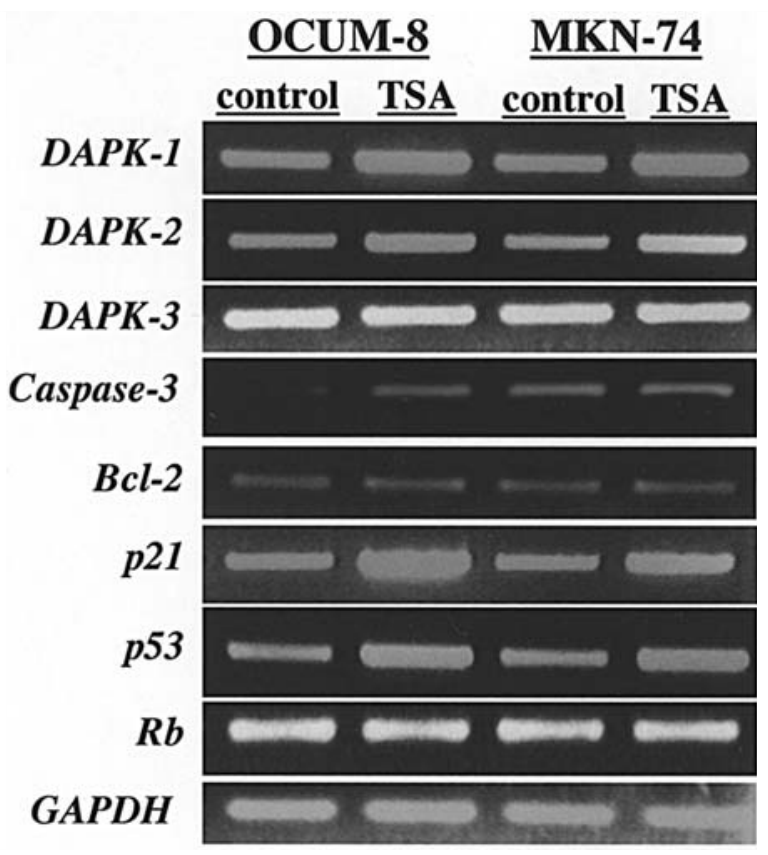

Figure 2. Effect of TSA on gene expression by RT-PCR. Expression of $D A P K-1, D A P K-2, p 21$ and $p 53$ increased in the OCUM-8 and MKN-74 cells. The expression of caspase-3 increased in OCUM-8, but not in MKN-74; in addition, the expression of $b c l-2, D A P K-3$ and $R b$ did not change in either cell line.

the proliferation of cancer cells in both cell lines. The proliferation rate by TSA was 84.8 and $94.4 \%$ in the OCUM- 8 and MKN-74 cells, respectively. Anticancer drugs were added to the cancer cell cultures at a concentration causing $50 \%$ growth inhibition $\left(\mathrm{IC}_{50}\right)$ for each cell line. Table II shows the $\mathrm{IC}_{50}$ of OCUM-8 and MKN-74 cells to 5 anticancer drugs. The proliferation rate by combined-exposure was evaluated by comparison with the expected additive effect. The proliferation rates for the OCUM- 8 cells by 5-FU, PTX, OXA, SN38 or GEM were $51.4,40.1,61.3,40.6$ and $61.6 \%$, respectively. The proliferation rates for OCUM-8 cells by the combination of TSA plus 5-FU, PTX, OXA, SN38 or GEM were 41.0, 31.8, 58.1, 28.8 and $45.1 \%$, respectively. The combination of TSA and 5-FU, PTX, SN38 or GEM showed a synergistic effect, while TSA plus
OXA showed a semi-additive effect. The proliferation rates for the MKN-74 cells by TSA, 5-FU, PTX, OXA, SN38 or GEM were 48.5, 39.1, 36.7, 53.7 and $46.3 \%$, respectively. The proliferation rates for the MKN-74 cells by TSA plus 5-FU, PTX, OXA, SN38 or GEM were 40.7, 31.0, 33.9, 41.5 and $45.3 \%$, respectively. The combination of TSA and 5-FU, PTX, OXA or SN38 showed a synergistic effect, while TSA plus GEM showed a semi-additive effect.

Effect of TSA on expression of apoptosis-regulating proteins in gastric cancer cells. TSA increases the expression of $p 21$, p53, DAPK-1 and the DAPK-2 gene in both OCUM-8 and MKN-74 cells. TSA treatment increased the expression of caspase-3 in OCUM-8, but not in MKN-74. The DAPK-3, bcl-2 and $R b$ genes did not show any alteration by TSA treatment (Fig. 2).

\section{Discussion}

In this study, TSA increased the chemosensitivity of anticancer drugs in human gastric cancer cells. A synergistic antiproliferative effect by the combination of TSA was observed in 5-FU, PTX or SN38. 5-FU is a pyrimidine antagonist that inhibits DNA synthesis and blocks the production of RNA. PTX is a kind of taxane-based drug that interferes with mitosis and cell replication by binding to a subunit of tubulins. SN38 is a DNA topoisomerase I inhibitor that interferes with DNA replication and cell division. These 3 anticancer drugs have different mechanisms, and are frequently used clinically. PTX and SN38 are generally used weekly or biweekly. The adminis-tration of TSA for $48 \mathrm{~h}$ enhanced these genetic changes. Taken together, because no antagonistic interactions were found in the combination of TSA with the 5 anti-cancer drugs examined in this study, TSA has wide chemotherapeutic efficacy with various types of anticancer drugs in gastric carcinoma. It has been reported that $500 \mathrm{ng} / \mathrm{ml} \mathrm{TSA}$ significantly inhibited the growth of gastric cancer cells (25). In this study, a low dose of TSA $(30 \mathrm{ng} / \mathrm{ml})$ showed a synergistic effect with anticancer drugs. Since TSA is reported to be toxic (26), a low dose of TSA is appropriate for clinical use. Because these genetic alterations of mRNA by the HDAC inhibitor are reversible, two days of administration of TSA with PTX or SN38 in a week might be safe. To our knowledge, this is the first report stating that TSA shows a synergistic effect in combination with anticancer drugs in gastric cancer.

HDAC inhibitors are capable of inducing apoptosis and cell cycle arrest at the $\mathrm{G} 1$ or $\mathrm{G} 2$ phase by the alteration of gene expressions (15-17,21,27-30). In our study, DAPK-1 and $D A P K-2$ were up-regulated by TSA in gastric cancer cells, but not $D A P K-3 . D A P K-1$ and $D A P K-2$ are responsible for the induction of apoptosis, while DAPK-3 usually induces morphological changes in apoptosis (31). The loss of DAPK expression has been documented in many cancer types $(24,30,32,33)$. These findings suggest that DAPK-1 and DAPK-2 might participate in the synergism by the co-treatment of TSA and anticancer drugs.

It has been well proven that HDAC inhibitors could upregulate the transcription of both p53 and p21 (17,34-36), and that they could also induce the hypophosphorylated form of 
$\mathrm{Rb}$ (21), which usually leads to a cell cycle arrest at the G1 phase. Consistent with the previous study, our study also shows that TSA enhanced the expression of $p 53$ as well as $p 21$, while the mRNA level of $R b$ was not changed by TSA. The cell cycle is regulated by a complicated network that involves a number of regulators, such as p21 $1^{\mathrm{WAF} 1 / \mathrm{CIP} 1}$, p53 and Rb. P21 was initially discovered as a negative regulator of cell cycle progression. Since OCUM-8 and MKN-74 cells possess the wild $p 53$ gene, the p 21 might be up-regulated by TSA and/or p53.

The expression level of caspase- 3 mRNA increased in OCUM-8 but not MKN-74, suggesting that caspase-3 might take part in chemosensitivity increased by TSA. Although no study supports that the transcription of caspase- 3 can be upregulated directly by histone acetylation, recent evidence suggests that HDAC inhibitors also enhance the acetylation of non-histone proteins $(37,38)$. No alteration of bcl-2 was presented after $48 \mathrm{~h}$ exposure to TSA, indicating that the bcl-2 family might not contribute to the enhanced chemosensitivity of TSA.

In conclusion, TSA increased the chemosensitivity of anticancer drugs of 5-FU, PTX and SN38 in gastric cancer cells. The up-regulation of $p 53, p 21, D A P K-1$ and $D A P K-2$ might explain the mechanism of synergism.

\section{Acknowledgements}

This study was partially funded by Japan-China Sasagawa Medical Scholarship, and by a Grant-in-Aid for the Osaka City University Medical Research Foundation.

\section{References}

1. Jemal A, Thomas A, Murray T and Thun M: Cancer statistics, 2002. CA Cancer J Clin 52: 23-47, 2002.

2. Parkin DM: Global cancer statistics in the year 2000. Lancet Oncol 2: 533-543, 2001.

3. Correale P, Fulfaro F, Marsili S, Cicero G, Bajardi E, Intrivici C, Vuolo G, Carli AF, Caraglia M, Del Prete S, Greco E, Gebbia N and Francini G: Gemcitabine (GEM) plus oxaliplatin, folinic acid and 5-fluorouracil (FOLFOX-4) in patients with advanced gastric cancer. Cancer Chemother Pharmacol 56: 563-568, 2005.

4. Ajani JA, Fairweather J, Pisters PW and Charnsangavej C: Irinotecan and cisplatin in advanced gastric or gastroesophageal junction carcinoma. Oncology 14: 19-21, 2000.

5. Louvet C, Andre T, Tigaud JM, Gamelin E, Douillard JY, Brunet R, Francois E, Jacob JH, Levoir D, Taamma A, Rougier P, Cvitkovic E and De Gramont A: Phase II study of oxaliplatin, fluorouracil and folinic acid in locally advanced or metastatic gastric cancer patients. J Clin Oncol 20: 4543-4548, 2002.

6. Murad AM, Petroianu A, Guimaraes RC, Aragao BC, Cabral LO and Scalabrini-Neto AO: Phase II trial of the combination of paclitaxel and 5-fluorouracil in the treatment of advanced gastric cancer: a novel, safe, and effective regimen. Am J Clin Oncol 22: 580-586, 1999.

7. Schniewind B, Christgen M, Kurdow R, Haye S, Kremer B, Kalthoff $\mathrm{H}$ and Ungefroren $\mathrm{H}$ : Resistance of pancreatic cancer to gemcitabine treatment is dependent on mitochondria-mediated apoptosis. Int J Cancer 109: 182-188, 2004.

8. Fang JY and Lu YY: Effects of histone acetylation and DNA methylation on p21(WAF1) regulation. World J Gastroenterol 8: 400-405, 2002.

9. Monneret C: Histone deacetylase inhibitors. Eur J Med Chem 40: 1-13, 2005.

10. Roy S, Packman K, Jeffrey R and Tenniswood M: Histone deacetylase inhibitors differentially stabilize acetylated p53 and induce cell cycle arrest or apoptosis in prostate cancer cells. Cell Death Differ 12: 482-491, 2005.
11. Akino K, Toyota M, Suzuki H, Mita H, Sasaki Y, Ohe-Toyota M, Issa JP, Hinoda Y, Imai $\mathrm{K}$ and Tokino T: The Ras effector RASSF2 is a novel tumor-suppressor gene in human colorectal cancer. Gastroenterology 129: 156-169, 2005.

12. Bode AM and Dong Z: Post-translational modification of $\mathrm{p} 53$ in tumorigenesis. Nat Rev Cancer 4: 793-805, 2004.

13. Richon VM, Emiliani S, Verdin E, Webb Y, Breslow R, Rifkind RA and Marks PA: A class of hybrid polar inducers of transformed cell differentiation inhibits histone deacetylases. Proc Natl Acad Sci USA 95: 3003-3007, 1998.

14. Yoshida M, Kijima M, Akita M and Beppu T: Potent and specific inhibition of mammalian histone deacetylase both in vivo and in vitro by trichostatin A. J Biol Chem 265: 17174-17179, 1990.

15. Neuzil J, Swettenham E and Gellert N: Sensitization of mesothelioma to TRAIL apoptosis by inhibition of histone deacetylase: role of Bcl-xL down-regulation. Biochem Biophys Res Commun 314: 186-191, 2004.

16. Choi YH: Induction of apoptosis by trichostatin A, a histone deacetylase inhibitor, is associated with inhibition of cyclooxygenase-2 activity in human non-small cell lung cancer cells. Int J Oncol 27: 473-479, 2005.

17. Donadelli M, Costanzo C, Faggioli L, Scupoli MT, Moore PS, Bassi C, Scarpa A and Palmieri M: Trichostatin A, an inhibitor of histone deacetylases, strongly suppresses growth of pancreatic adenocarcinoma cells. Mol Carcinog 38: 59-69, 2003.

18. Kelly WK, O'Connor OA, Krug LM, Chiao JH, Heaney M, Curley T, MacGregore-Cortelli B, Tong W, Secrist JP, Schwartz L, Richardson S, Chu E, Olgac S, Marks PA, Scher H and Richon VM: Phase I study of an oral histone deacetylase inhibitor, suberoylanilide hydroxamic acid, in patients with advanced cancer. J Clin Oncol 23: 3923-3931, 2005.

19. Shiraga T, Tozuka Z, Ishimura R, Kawamura A and Kagayama A: Identification of cytochrome P450 enzymes involved in the metabolism of FK228, a potent histone deacetylase inhibitor, in human liver microsomes. Biol Pharm Bull 28: 124-129, 2005.

20. Karagiannis TC, Smith AJ and El'Osta A: Radio- and chemosensitization of human erythroleukemic K562 cells by the histone deacetylase inhibitor Trichostatin A. Hell J Nucl Med 7: 184-191, 2004.

21. Wetzel M, Premkumar DR, Arnold B and Pollack IF: Effect of trichostatin A, a histone deacetylase inhibitor, on glioma proliferation in vitro by inducing cell cycle arrest and apoptosis. $\mathrm{J}$ Neurosurg 103: 549-556, 2005.

22. Takemura S, Yashiro M, Sunami T, Tendo M and Hirakawa K: Novel models for human scirrhous gastric carcinoma in vivo. Cancer Sci 95: 893-900, 2004.

23. Niigata HHJ: Establishment of cultured cell lines of human stomach cancer origin and their morphological characteristics. Exp Med 91: 737-763, 1977.

24. Wang WJ, Kuo JC, Yao CC and Chen RH: DAP-kinase induces apoptosis by suppressing integrin activity and disrupting matrix survival signals. J Cell Biol 159: 169-179, 2002.

25. Suzuki T, Yokozaki H, Kuniyasu H, Hayashi K, Naka K, Ono S, Ishikawa T, Tahara E and Yasui W: Effect of trichostatin A on cell growth and expression of cell cycle- and apoptosis-related molecules in human gastric and oral carcinoma cell lines. Int $\mathbf{J}$ Cancer 88: 992-997, 2000.

26. Saito A, Yamashita T, Mariko Y, Nosaka Y, Tsuchiya K, Ando T, Suzuki T, Tsuruo T and Nakanishi O: A synthetic inhibitor of histone deacetylase, MS-27-275, with marked in vivo antitumor activity against human tumors. Proc Natl Acad Sci USA 96: 4592-4597, 1999.

27. Archer SY, Johnson J, Kim HJ, Ma Q, Mou H, Daesety V, Meng S and Hodin RA: The histone deacetylase inhibitor butyrate down-regulates cyclin B1 gene expression via a p21/WAF-1dependent mechanism in human colon cancer cells. Am J Physiol Gastrointest Liver Physiol 289: G696-G703, 2005.

28. Sakimura R, Tanaka K, Nakatani F, Matsunobu T, Li X, Hanada M, Okada T, Nakamura T, Matsumoto Y and Iwamoto Y: Antitumor effects of histone deacetylase inhibitor on Ewing's family tumors. Int J Cancer 116: 784-792, 2005.

29. Terui T, Murakami K, Takimoto R, Takahashi M, Takada K, Murakami T, Minami S, Matsunaga T, Takayama T, Kato J and Niitsu Y: Induction of PIG3 and NOXA through acetylation of p53 at 320 and 373 lysine residues as a mechanism for apoptotic cell death by histone deacetylase inhibitors. Cancer Res 63: 8948-8954, 2003. 
30. Toyooka S, Toyooka KO, Miyajima K, Reddy JL, Toyota M, Sathyanarayana UG, Padar A, Tockman MS, Lam S, Shivapurkar N and Gazdar AF: Epigenetic down-regulation of death-associated protein kinase in lung cancers. Clin Cancer Res 9: 3034-3041, 2003.

31. Kogel D, Prehn JH and Scheidtmann KH: The DAP kinase family of pro-apoptotic proteins: novel players in the apoptotic game. Bioessays 23: 352-358, 2001

32. Yu H, Jiang D, Guo Z, Saiyin H, Guo J, Wang X and Yu L: TCP10L is expressed specifically in spermatogenic cells and binds to death associated protein kinase-3. Int J Androl 28: 163-170, 2005

33. Satoh A, Toyota M, Itoh F, Kikuchi T, Obata T, Sasaki Y, Suzuki H, Yawata A, Kusano M, Fujita M, Hosokawa M, Yanagihara K, Tokino T and Imai K: DNA methylation and histone deacetylation associated with silencing DAP kinase gene expression in colorectal and gastric cancers. Br J Cancer 86: 1817-1823, 2002.

34. Joseph J, Wajapeyee N and Somasundaram K: Role of p53 status in chemosensitivity determination of cancer cells against histone deacetylase inhibitor sodium butyrate. Int J Cancer 115: 11-18, 2005.
35. Kitazono M, Bates S, Fok P, Fojo T and Blagosklonny MV: The histone deacetylase inhibitor FR901228 (desipeptide) restores expression and function of pseudo-null p53. Cancer Biol Ther 1: 665-668, 2002.

36. Sandor V, Senderowicz A, Mertins S, Sackett D, Sausville E, Blagosklonny MV and Bates SE: P21-dependent g(1)arrest with down-regulation of cyclin D1 and up-regulation of cyclin E by the histone deacetylase inhibitor FR901228. Br J Cancer 83: 817-825, 2000.

37. Yu X, Guo ZS, Marcu MG, Neckers L, Nguyen DM, Chen GA and Schrump DS: Modulation of p53, ErbB1, ErbB2 and Raf-1 expression in lung cancer cells by depsipeptide FR901228. J Natl Cancer Inst 94: 504-513, 2002.

38. Blagosklonny MV, Robey R, Sackett DL, Du L, Traganos F, Darzynkiewicz Z, Fojo T and Bates SE: Histone deacetylase inhibitors all induce p21 but differentially cause tubulin acetylation, mitotic arrest and cytotoxicity. Mol Cancer Ther 1: 937-941, 2002. 